\title{
THE RELATIONSHIP BETWEEN INTERNAL AND EXTERNAL AUDIT
}

\author{
Professor PhD Atanasiu Pop, ,Babeş-Bolyai” University of Cluj-Napoca, \\ e-mail:apop@econ.ubblcuj.ro \\ PhD Student Cristina Boța-Avram, ,Babeş-Bolyai” University of Cluj-Napoca, e-mail: \\ botaavram@gmail.com \\ PhD Student Florin Boța-Avram, ,Babeş Bolyai” University of Cluj-Napoca, e-mail: \\ botaavramflorin@yahoo.com
}

\begin{abstract}
Analyzing the evolution process of internal audit, from its beginnings and so far, we can easily notice that internal audit function was born through detaching of some activities from external audit, the result being that there some situations when these two functions could be easily confused. The reality is that internal audit and external audit are two distinctive functions; net differenced, but which are also characterized through some complementary relationships. In this paper, we try to give our contribution at the clarification of the similarities and differences between these two functions, making a literature review that allowed us to identify some very interesting studies that permitted us to emphasize the main criterions that influenced the relationship between internal audit and external audit.
\end{abstract}

Keywords: internal audit, external audit, objectivity, competence

JEL Codes: M42

\section{Introduction}

The coordination of internal audit activity with external audit activity is very important from both points of view: from external audit's point of view is important because, in this way, external auditors have the possibility to raise the efficiency of financial statements audit; the relevancy from internal audit's point of view is assured by the fact that this coordination assures for the internal audit a plus of essential information in the assessment of risks control (Dobroțeanu, L.\& Dobroțeanu C.L., 2002).

The importance of the relationship from internal audit and external audit is reflected also by International Standards of Audit (610 - ,Considering the work of internal audit”), which foresees, among others:

$>$ The role of internal auditing is determined by management, and its objectives differ from those of the external auditor who is appointed to report independently on the financial statements. The internal audit function's objectives vary according to management's requirements. The external auditor's primary concern is whether the financial statements are free of material misstatements;

$>$ The external auditor should obtain a sufficient understanding of internal audit activities to identify and assess the risks of material misstatement of the financial statements and to design and perform further audit procedures;

$>$ The external auditor should perform an assessment of the internal audit function, when internal auditing is relevant to the external auditor's risk assessments;

$>$ Liaison with internal auditing is more effective when meetings are held at appropriate intervals during the period. The external auditor would need to be advised of and have access to relevant internal auditing reports and be kept informed of any significant matter that comes to the 
internal auditor's attention which may affect the work of the external auditor. Similarly, the external auditor would ordinarily inform the internal auditor of any significant matters which may affect internal auditing;

\section{Studies regarding the relationship between internal audit and external audit}

The first relevant study regarding the interaction between internal audit and external audit was realized by Mautz R. (1984), and the results of this study showed that, from internal audit's point of view, the relationship with external audit is only ostensibly a very good one. Because Mautz had not anticipated the existence of such negative reactions from internal auditors, regarding their working with external auditors, questions addressing causality were omitted from his survey.

Later, Peacock E. and Pelfrey S. (1989) realized a survey through they tried to assess the current attitudes of internal auditors toward their working relationships with external auditors, trying also to identify the reasons behind any negative attitudes which were expressed. This survey was conducted of two groups: first group was represented by internal audit directors, and the second group was formed by staff auditors who work directly which external auditors. Both groups were asked to evaluate the overall performance of their organization's external auditor and their perceived relationship with the external auditor. Next, we present the main results obtained through this survey:

- $92 \%$ from internal audit directors appreciated that external auditors make full use of the expertise of the internal audit staff;

- $50 \%$ of internal audit directors perceived that relationship between internal audit and external audit is an "excellent" one, while 31\% appreciate this relationship as "good";

- Staff auditors differed substantially in their perceptions of the external auditors' of the internal auditor's expertise. Only 39\% of staff auditors considered that the external auditors fully utilized their expertise;

- Starting from the statement of Morris N. (Morris N., 1981) that "the external audit firm has the ear of the board of directors and, where one is established, the audit committee. Internal auditors do not have the same relationship", Peacock E. and Pelfrey S. wanted to identify the relationship between internal audit and audit committee. From this point of view, more that $80 \%$ of the respondent directors of their study indicated that their companies have an audit committee, and that the internal audit department has a defined reporting relationship with that committee;

- The majority of the respondent directors reported that they were furnished access to the letter of external audit either before or after presentation to the board of directors. They are also asked to comment on its findings;

- Another conclusion of this survey was that, generally, individual external auditors do not recognize the contribution of individual internal audit staffs, internal auditors considering that that they perform more than one third of the external audit work;

- General conclusion of this survey was that internal audit directors perceived a good relationship between internal and external auditors, and this perception could be the result of company policies which give internal auditing (1) a direct reporting relationship to the audit committee of the board of directors, and (2) the opportunity to respond to any criticism by the external auditors in the management letters;

- Internal auditing emphasizes operational auditing and may involve non-financial data, whereas financial auditing is concerned primarily with historical data, in order to be able to identify possible ways of improving future business operations. Internal audit staffs consider their external audit tasks to be less important that the work they perform as operational auditors. 
Another study with a relevant contribution at the researching of the relationship between internal and external audit was conducted by Reinstein A., Lander G.H. and Gavin T.A. (1994). The starting point of this survey was assured by Statement on Auditing Standards (SAS) 65 issued in April 1991 by The American Institute of Certified Public Accountants (AICPA). SAS 65 "The Auditor's Consideration of the Internal Audit Function in an Audit of Financial Statements" whose main objective was to clarify various aspects of the working relationship which should exist between external and internal auditors. This standard issued by AICPA proposes to establish new guidelines for external auditors, to help them to use the result of internal audit activity more effectively and efficiently; to help external auditors to understand how could they adapt their working procedures based on internal auditor's work, and also how to assess, evaluate and test the internal auditor's competence, objectivity and work. External auditors should: (1) understand the internal auditor's role when assessing their client's control structure and (2) not accept the internal auditor's work as their own. The respondents of this study realized by Reinstein A., Lander G.H. \&Gavin T.A. were divided in four groups: (1) the chief internal auditor (IA); (2) the chief financial officer (CFO) (3) the chair of the audit committee (AC) and (4) the external auditor (EA) in charge of the audit. The survey concerned on three major points: the testing of general understanding of financial statements audit realized by internal auditors; the testing of the assessment realized by external audit regarding the internal audit's competence; the testing of the assessment of internal audit's objectivity. General conclusion was that, in most organizations, internal and external auditors have developed a "teamwork" approach to the audit for some time, and the provisions of SAS 65 appear to have had minimal effect on these types of relationships. In situations where the internal audit staffs do not maintain the required level of professionalism or the organization is changing auditing firms, external auditors now have new guidance to help them use internal auditors more effectively and efficiently. Given the recent increase in the stature of the internal audit professional and the need for external auditors to control audit costs, SAS 65 should serve both types of auditors well as they co-ordinate their efforts.

A major part of external auditors trust to the results of internal audit activity, and this confidence is going to grow quite fast in the next future (Ward, D.D. \& Robinson, J.C., 1980). Schneider (1984) realized a descriptive model study through he examined three major factors of internal auditing that have big influences over the confidence of external audit in the internal auditing: (1) objectivity (2) competence and (3) work performed.

The results obtained by Schneider showed that, from external auditors' point of view, the most important factor is the quality of the work performed by internal audit, next important factors being competence and objectivity. The competence is defined by Arens and Loebbecke (1991) as being that quality of a person that accepts a professional engagement and which also has the necessary technical knowledge in order to fulfill that engagement.

Maletta (1993) examined the effect of inherent risk on the extent to which internal auditors' objectivity, competence and work performed affected external auditors' decisions to rely on them. The conclusion was that all three factors affected external auditors' reliance judgment. There were significant interactions between "objectivity" and "competence", between "objectivity" and "work performed" and three way interactions among those factors. The significant three way interactions suggested that inherent risk does affect external auditors' reliance decisions. The results also showed that when inherent risk is high, external auditors consider the nature of the previous work performed by internal auditors only when internal auditors' objectivity is high. When inherent risk is low, work performed has no significant effect on external auditors' judgment. Also, external auditors appeared to use more complex configurable decision processes only when inherent risk is high. Across inherent risk conditions, internal auditors' "competence" is the most important of the three factors, followed by "objectivity" and "work performed". 
Another relevant study was conducted by Berry L. (1984), which examined the coordination of the relationship between internal and external audit, from internal audit's point of view. The performance of the study was that it succeeded to identify the main criterions for the assessment of competency, objectivity and performance of internal auditor. This study also established a coordination program for the relationship between these two functions - internal and external audit.

A common element of the studies mention before is that there are identified three major criterions that influenced the confidence given to the internal audit by external audit: competence, objectivity and the nature of the work performed by internal audit.

In the same direction, we identified another relevant study realized by Haron H., Chambers A., Ramsi R. and Ismail I. (2004). Starting point of this survey is given by the fact that external auditors often rely on other professionals for the audit of the financial statements of their clients. Generally, external auditors rely on clients' internal auditors. Reliance on internal auditors results in cost savings to the client. The objective of this study was to determine which of the criterions used by external auditors in the evaluation of internal audit activity (objectivity, competency and the quality of work performed by internal audit) has major influences over the decision of considering the results of internal audit activity. The findings of the study indicated that technical competence and work performed are the two most important criterions that external auditors consider in their reliance on internal auditors. The objectivity of internal audit is not considered as being significant, from external auditor's point of view, a possible explanation being the fact that internal auditors are seen as the employees of the organization, so objectivity is not an important element that could affect the decisions of external auditors regarding their reliance on internal auditors.

The results showed that, from "competency" criterion's point of view, external auditors view only an ongoing training program that includes a thorough coverage of the company's operations, policies and procedures to be an important element for them to rely on the internal auditors. Professional certification of internal auditors was not viewed as important. Under the "work performed" criterion, external auditors placed importance on whether the follow-up procedures on deficiencies in the company systems, methods, and/or procedures noted in prior audits were satisfactory. This could be due to the fact that the follow-up procedures could be an indication of the quality of work performed by the internal auditors.

These criterions, "competency" and "work performed" identified by Haron H., Chambers A., Ramsi R. and Ismail I. (2004) are consistent with previous studies (Maletta M., 1993; Tiessen P. \& Colson R.H., 1990; Schneider A., 1984). Next, we present a short synthesis of the most important surveys regarding the important criterions that external auditors take into consideration in their reliance on internal auditors

Table no. 1

Significant criterions in the decision process regarding the reliance of external auditors on internal auditors

\begin{tabular}{|l|l|}
\hline \multicolumn{1}{|c|}{ Study } & \multicolumn{1}{c|}{ Findings } \\
\hline Brown, R.P. (1983) & Independence/objectivity; Work performed; \\
\hline Schneider, A.(1984) & Work performed; Competence; \\
\hline Tiessen, P. \& Colson, R.H. (1990) & Work performed; Competence; Objectivity; \\
\hline Maletta, M. (1993) & Objectivity; Competence; Work performed; \\
\hline Haron H. et al., (2004) & Competence; Work performed; \\
\hline
\end{tabular}

Source: Haron H. et al. ( 2004)

Through this review of the main studies regarding the relationship between internal and external audit, we consider that we succeeded to emphasize some significant aspects that influences this relationship. In spite of the fact that these two functions are net differenced, there could be 
identified some complementary relationships whose good practical applying assures for the whole organization a guarantee of efficacy.

\section{Similarities and differences between internal audit and external audit}

\section{external audit:}

Next, we present the main similarities that could be identified between internal and

$>$ Both internal audit and external audit profession are governed by one set of international standards issued by the professional organism specific for each profession. This set of international standards includes the professional standards and the ethical code;

$>$ Risk is a very important element the planning process for both internal and external auditors;

$>$ For both professions, the independence of the auditor is very important;

$>$ Internal and external audit are both concerned over the internal control system of the organization;

Both functions are interested in the cooperation between internal and external auditors;

$>$ For both functions, the results of their activity are presented through audit reports;

Continuing our research activity, next we will try to underline the main differences between internal and external audit functions:

Table no. 2

The main differences between internal and external audit functions

\begin{tabular}{|c|c|c|c|}
\hline No. & Criterions & Internal Audit & External audit \\
\hline 1. & $\begin{array}{l}\text { Position inside } \\
\text { the } \\
\text { organization }\end{array}$ & $\begin{array}{l}\text { The internal auditors' are part of the } \\
\text { organization. Their objectives are } \\
\text { determined by professional standards, } \\
\text { the board, and management. Their } \\
\text { primary clients are management and the } \\
\text { board. }\end{array}$ & $\begin{array}{l}\text { External auditors are not part of the } \\
\text { organization, but are engaged by it. Their } \\
\text { objectives are set primarily by statute and } \\
\text { their primary client - the board of } \\
\text { directors. }\end{array}$ \\
\hline 2. & Objectives & $\begin{array}{l}\text { The internal auditor's scope of work is } \\
\text { comprehensive. It serves the } \\
\text { organization by helping it accomplish } \\
\text { its objectives, and improving } \\
\text { operations, risk management, internal } \\
\text { controls, and governance processes. } \\
\text { Concerned with all aspects of the } \\
\text { organization - both financial and non- } \\
\text { financial - the internal auditors focus on } \\
\text { future events as a result of their } \\
\text { continuous review and evaluation of } \\
\text { controls and processes. }\end{array}$ & $\begin{array}{l}\text { The primary mission of the external } \\
\text { auditors is to provide an independent } \\
\text { opinion on the organization's financial } \\
\text { statements, annually. }\end{array}$ \\
\hline 3. & Independence & $\begin{array}{l}\text { Internal audit must be independent from } \\
\text { the audited activities. }\end{array}$ & $\begin{array}{l}\text { External audit is independent from its } \\
\text { client, the organization, its independence } \\
\text { being specific to liberal professions. }\end{array}$ \\
\hline 4. & $\begin{array}{l}\text { Approach of } \\
\text { internal } \\
\text { control }\end{array}$ & $\begin{array}{l}\text { Internal audit regards all the aspects } \\
\text { regarding the organization's internal } \\
\text { control system. }\end{array}$ & $\begin{array}{l}\text { External audit regards the internal control } \\
\text { system only from the materiality } \\
\text { perspective, which permits them to } \\
\text { eliminate those errors that aren't } \\
\text { significant, because they don't have } \\
\text { influences over the financial results. }\end{array}$ \\
\hline 5. & $\begin{array}{l}\text { Applying } \\
\text { the audit }\end{array}$ & $\begin{array}{l}\text { Internal audit covers all the } \\
\text { organization' transactions. }\end{array}$ & $\begin{array}{l}\text { External audit covers only those } \\
\text { operations that have a contribution at the } \\
\text { financial results and the performances of } \\
\text { the organization. }\end{array}$ \\
\hline
\end{tabular}




\begin{tabular}{|c|c|c|c|}
\hline 6. & $\begin{array}{l}\text { Frequency of } \\
\text { the audit }\end{array}$ & $\begin{array}{l}\text { Internal audit performs during the entire } \\
\text { year, having specific missions } \\
\text { established in according with the level } \\
\text { of risks identified for each auditable } \\
\text { entity. }\end{array}$ & $\begin{array}{l}\text { External audit is an activity with a yearly } \\
\text { frequency, as a rule, at the end of the year. }\end{array}$ \\
\hline 7. & $\begin{array}{l}\text { Approach of } \\
\text { risk }\end{array}$ & $\begin{array}{l}\text { The importance of risk for the planning } \\
\text { of internal audit activity is very high, } \\
\text { the assessment of risk being combined } \\
\text { with other types of information like } \\
\text { financial and operational. }\end{array}$ & $\begin{array}{l}\text { External audit uses the information of } \\
\text { risks for the determination of nature, } \\
\text { period of time and necessary audit } \\
\text { procedures that should be performed in } \\
\text { the auditable area, taking into } \\
\text { consideration only financial aspects. }\end{array}$ \\
\hline 8. & $\begin{array}{l}\text { Consideration } \\
\text { of risk factors }\end{array}$ & $\begin{array}{l}\text { Internal audit takes into consideration at } \\
\text { least next risk factors: (Colbert, J.L., } \\
\text { 1995): } \\
>\text { Ethical climate and pressure on } \\
\text { management to meet objectives; } \\
\text { > Competency, adequacy, and integrity } \\
\text { of personnel; } \\
\text { } \text { Asset size, liquidity, or transaction } \\
\text { volume; } \\
\text { > Financial and economic conditions; } \\
>\text { Competitive conditions; } \\
>\text { Impact of customers, suppliers, and } \\
\text { government regulations; } \\
>\text { Date and result of previous audits; } \\
\text { Degree of computerization; } \\
>\text { Geographic dispersion of operations; } \\
>\text { Adequacy and effectiveness of the } \\
\text { system of internal control; } \\
\text { Organizational, } \\
\text { technological, or economic changes; } \\
>\text { Management judgments and } \\
\text { accounting estimates; } \\
>\text { Acceptance of audit findings and } \\
\text { corrective action taken; }\end{array}$ & $\begin{array}{l}\text { External audit takes into consideration } \\
\text { next risk factors: (Colbert, J.L., 1995): } \\
\text { Management operating and financial } \\
\text { decisions are dominated by a single } \\
\text { person; } \\
\text { Management's attitude toward financial } \\
\text { reporting is unduly aggressive; } \\
\text { Management, particularly senior } \\
\text { accounting personnel, turnover is high; } \\
\text { - Management places undue emphasis } \\
\text { on meeting earnings projections; } \\
\text { Management's reputation in the } \\
\text { business community is poor; } \\
\text { Profitability of entity relative to its } \\
\text { industry is inadequate or inconsistent; } \\
\text { Sensitivity of operating results to } \\
\text { economic factors is high; } \\
\text { Rate of change in entity's industry is } \\
\text { rapid; } \\
\text { Entity's industry is declining with } \\
\text { many business failures; } \\
\text { Organization is decentralized without } \\
\text { adequate monitoring; } \\
\text { Internal or external matter raises } \\
\text { substantial doubt about the entity's } \\
\text { ability to continue as a going concern; } \\
\text { Contentious or difficult accounting } \\
\text { issues are prevalent; } \\
\text { There are significant and unusual } \\
\text { related party transactions not in the } \\
\text { ordinary course business; } \\
\text { The nature, cause (if known), or } \\
\text { amount of known and likely } \\
\text { misstatements detected in the audit of } \\
\text { prior period's financial statements is } \\
\text { significant; } \text { Client is new with no prior audit } \\
\text { history or sufficient information is not } \\
\text { available from the predecessor auditor. }\end{array}$ \\
\hline 9. & $\begin{array}{l}\text { Approach of } \\
\text { fraud }\end{array}$ & $\begin{array}{l}\text { Internal audit is concerned about the } \\
\text { frauds from all activities from the } \\
\text { organization. }\end{array}$ & $\begin{array}{l}\text { External audit is concerned only about the } \\
\text { fraud from financial areas. }\end{array}$ \\
\hline
\end{tabular}


As we mentioned before, between these two functions there could be identified some complementary relationships, identified also by Renard J. (2002), whose beneficiaries are especially practitioners, and the practical applying of these complementary relationships could assure the necessary premises for the growing of efficacy for the whole organization:

- Internal audit is a complement of external audit, because in those organizations where internal audit function is implemented, external audit is more determined to appreciate in a different manner the regularity, sincerity and fair view of the results and financial statements.

- External audit is a complement of internal audit, starting from the idea that where an external specialist made his job, it is certain that there is a better control. Also, internal auditor could have significant benefits as a result of external audit activity, in order to express his opinion or to argue his recommendations.

\section{Conclusions}

According to IIA's recommendations, the ideal situation is when the internal and external auditors meet periodically to discuss common interests; benefit from their complementary skills, areas of expertise, and perspectives; gain understanding of each other's scope of work and methods; discuss audit coverage and scheduling to minimize redundancies; provide access to reports, programs and working papers; and jointly assess areas of risk. In fulfilling its oversight responsibilities for assurance, the board should require coordination of internal and external audit work to increase economy, efficiency, and effectiveness of the overall audit process.

Auditing processes for both internal auditors and external auditors have changed in the past eight to ten years (Lemon, M.W.\& Tatum K.W., 2003). The main factors that prompted these changes included the globalization of business, advances in technology, and demands for valueadded audits. Figure no.1 illustrates these changes in practice, which initiated changes in both internal and external auditing standards: 


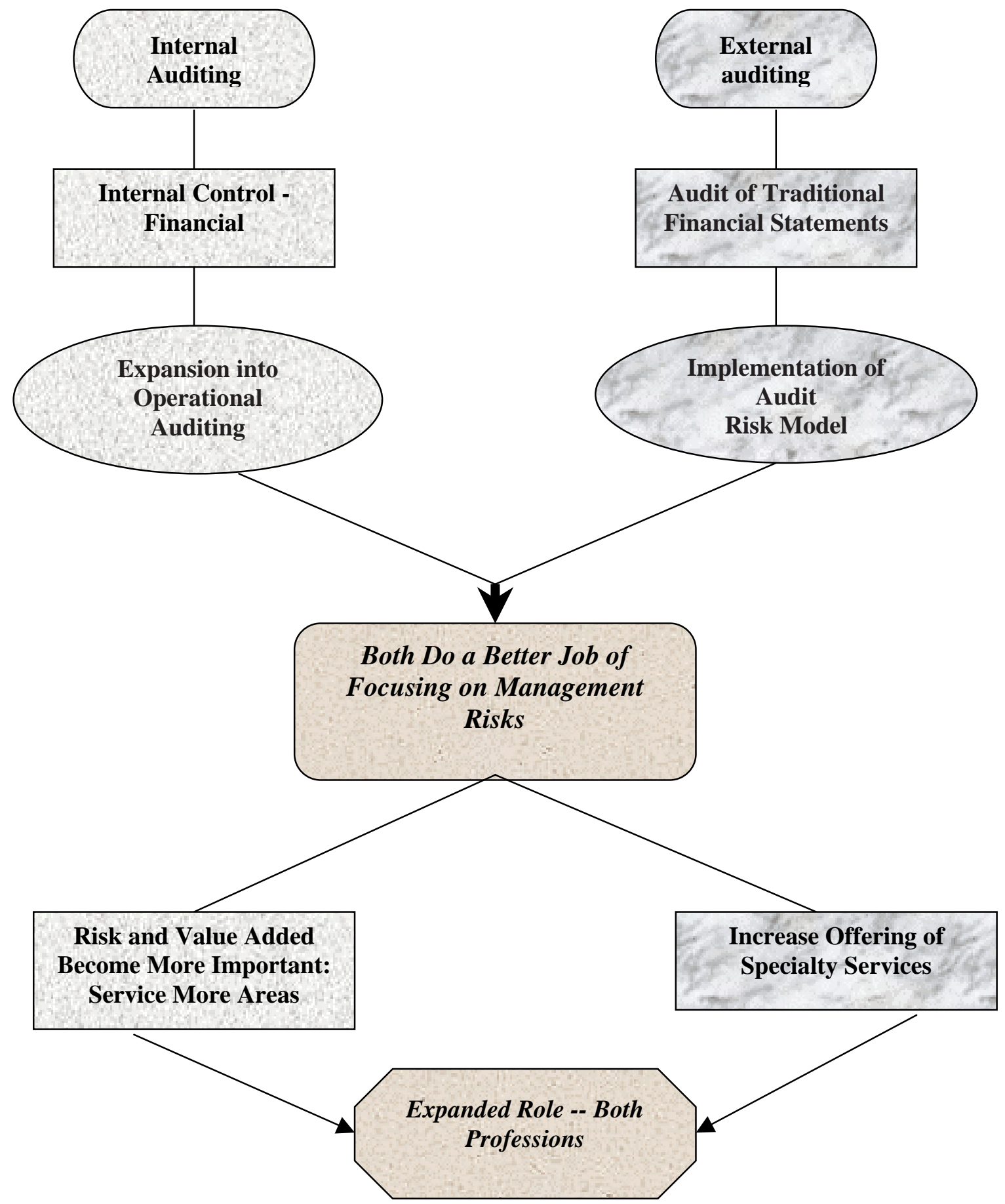

Fig.no.1 - Convergence of Internal Audit and External Audit Functions Source: Rittenberg, L.E. \& Covaleski, M. (1997)

\section{References}

1. Arens, A.A. \& Loebbecke, J.K. - Auditing: An Integrated Approach, Prentice-Hall International, Englewood Cliffs, 1991.

2. Berry, L. - Coordinating Total Audit Coverage: Trends and Practices, IIA Inc., Altamonte Springs, Florida, 1984.

3. Colbert, J.L. - Risk: internal and external auditors operate from two different, official definitions of risk, Internal Auditor, October, 1995.

4. Dobroțeanu, L.\& Dobroțeanu C.L. - Audit - concepte si practici, abordare națională şi internațională, Editura Economică, Bucureşti, 2002.

5. Haron, H. \& Chambers, A. \& Ramsi, R. \& Ismail, I. - The reliance of external auditors on internal auditors, Managerial Auditing Journal, 2004,Vol. 19 No. 9, pp. 1148-1159. 
6. Lemon, M.W.\& Tatum K.W., - Internal auditing's systematic, disciplined process, The Institute of Internal Auditors Research Foundation, 2003, accesibil on-line la www.theiia.org.

7. Maletta, M. - An examination of auditors' decision to use internal auditors as assistants: the effect of inherent risk, Journal of Contemporary Accounting Research, 1993, Vol. 9 No. 2.

8. Mautz, R. - Internal and external auditors: how do they relate?, Corporate Accounting, Vol.3 No.4, 1984, pp.56-58.

9. Peacock, E.\& Pelfrey, S. - How internal auditors view the external audit?, The Internal Auditor, June, 1989, Vol.46, pp.48-54.

10. Reinstein, A., \& Lander, G.H. \& Gavin, T.A. - The External Auditor's Consideration of the Internal Audit Function, Managerial Auditing Journal, Vol. 9 No. 7, 1994, pp. 29-36.

11. Renard J. - Teoria şi practica auditului intern, ediția a IV-a, Ministerul Finanțelor Publice, Bucureşti, 2002.

12. Rittenberg, L.E. \& Covaleski, M. - The Outsourcing Dilemma: What's Best for Internal Auditing, The Institute of Internal Auditors Research Foundation, Altamonte Springs, Florida, 1997.

13. Schneider, A. - Modelling external auditors' evaluations of internal auditing, Journal of Accounting Research, Vol. 22 No. 2, 1984,pp. 657-78.

14. Tiessen, P. \& Colson, R.H. - External auditor reliance on internal audit, Journal of Internal Auditing, Vol. 5 No. 3, 1990, pp. 10-22.

15. Ward, D.D. \& Robinson, J.C. - Reliance on internal auditors, Journal of Accountancy, October, 1980, pp. 62-73. 